\title{
THE ULTRASONIC WAY OF THE INTRAOPERATIVE ASSESS OF THE RESECTION VOLUME OF COLON IN CHILDREN WITH CHRONIC CONSTIPATION
}

\author{
Kirgizov I. V. ${ }^{1}$, Minaev S. V. ${ }^{2}$
}

${ }^{1}$ Head hospital of the general management department of presidential administration, Moscow, Russian Federation

2 Stavropol State Medical University, Russian Federation

$\mathbf{T}$ he chronic constipation (CCS) in childhood, in spite of the modern development of coloproctology, remains serious and in many aspects an unresolved problem [5]. The quantity of relapses of the disease after surgical treatment still remains high, reaches $20,0 \%$ and more [13, 14]. Therefore the choice of volume of an optimum level of resection is of great importance in depression of quantity of relapses after the surgical treatment. The differentiated approach applied now to surgical treatment in constipation is based on radiological data (a choice of the area with the most expressed stasis) and consists in resection of the zone of the faulty innervation of colon with excision of the decompensated organ parts $[1,3]$.

Ultrasonic diagnostics, being a non-invasive method, finds more and more wide application in medicine. The significant amount of works on this problem, are devoted to the transabdominal ultrasonic research $[6,15]$ and transrectal ultrasonography [2, 9] in inflammatory and oncologic diseases of colon. Improving techniques of ultrasonic research, L. M. Portnoy with coauthors at ultrasonic research of the stomach wall (1991) has allocated 4 layers. At the further development of ultrasonic techniques, in 1997 by K. V. Prozorovsky and V. S. Pruchansky, already 5 layers in the stomach wall were taped, that corresponds to its histological structure. Recently endoscopic ultrasonography of esophagus and stomach received great acknowledgment [11, 12], allowing to define 4 layers of the organ wall, but using of the given technique in coloproctology yet does not give possibility to differentiate parts of the investigated organ due to technical difficulties. In the same time the way of contact ultrasonic

Kirgizov Igor, MD, PhD, Professor, Head of Department of Pediatric Surgery Head hospital of the general management department of presidential administration, Moscow

tel.: 79057720953; e-mail: drkirgizov@yandex.ru

Minaev Sergey, MD, PhD, Professor, Head of Department of Pediatric Surgery Stavropol State Medical University;

tel.: 79624507653; e-mail: sminaev@yandex.ru research of superficially located structures allows to judge precisely enough about structure of subject tissues under the gauge [4, 7]. According to the literature, intraoperative contact research of the colon wall in patients with constipation by high-pitched gauges was not spent before. The purpose of the research was working out the way of an intraoperative estimation of level of the colon lesion in patients with constipation.

Material and Methods. Bench ultrasonic researches of various departments and colon sites were carried out on 30 histological specimens of colon - control group, consisted of autopsy material. Preliminary for signal intensifying, $10 \%$ gelatin solution was entered into the organ's cavity, for straightening colon walls. Estimation of the ultrasonic picture of an organ was performed on «Logiq-700» by gauge with the frequency $9 / 5-$ 11.0 MHz (a priority for the patent of the Russian Federation № 2000122800 from September, 5th, 2000). Thickness of each layer and the whole wall was estimated, degree of echogenicity (hipo hyper- and normoechoic) and architectonics features of each layer throughout colon was defined. Intraoperative ultrasonic research of colon was similarly carried out in 11 patients with decompensated form of constipation; preliminary per rectum the $10 \%$ gelatin solution was entered. Then ultrasonic research of the colon wall was carried out, dynamics of changes of the layers' and the whole wall thickness with estimation of changes of echogenicity degree was defined. Thus, after revealing of the patholological changes in the organ, operative treatment in volume, depending on the level of the wall lesion was carried out: from left sided hemicolectomy to subtotal colectomy. Morphological research of the resected parts of colon included macro-microscopical preparing by $\mathrm{V}$. V. Vorobyov with a propaint of tissues with pirofuchsin by A. P. Sorokin, colouring of sections with pirofuchsin by Van-Gizon, Resorcinum fuchsin by Veigert, silvering by Carup, hematoxylin and eosine. All digital material was exposed to necessary mathematical processing on the computer by means of standard pack of statistical programs. 
Results. Ultrasonic research of the colon wall in control group has taped 5 layers (Fig. 1), having characteristic signs. The caecum wall thickness (Table 1) in the haustration area according to ultrasonic research, makes $1.91 \pm 0.1 \mathrm{~mm}$, where the

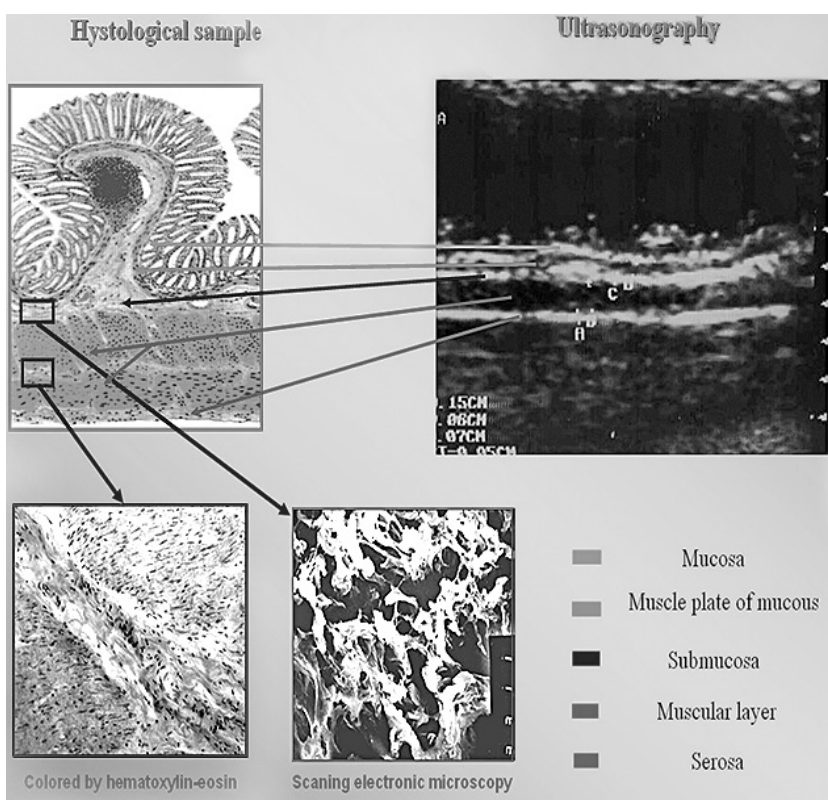

Fig.1. Comparative relationship between the morphological, histological structure, electron microscopy and an ultrasonography data of normal colon wall layers. (A different colon wall layer on ultrasonography has been showed by colored arrows. The multifrequency linear gauge $9.5 \mathrm{MHz}$ by «ogiq-700»)

following coats serous, muscular, submucous, a muscular plate of the mucous membrane and mucosa are allocated. At qualitative assessment of the serous coat, its hyperechoic structure attracts attention, the layer's thickness is thus peer $0.25 \pm 0.01 \mathrm{~mm}$. The muscular coat of caecum is hypoechoic by structure, thickness peer $0.58 \pm 0.09 \mathrm{~mm}$. No differences in structure of longitudinal and circular muscular layers at ultrasonic research were taped. Submucous cover has hyperechoic structure and thickness about $0.49 \pm 0.025 \mathrm{~mm}$. The muscular plate of mucous membrane is hypoechoic, its thickness is $0.21 \pm 0.01 \mathrm{~mm}$. At research of caecum mucous membrane, its hyperechoic structure attracts attention, thickness is thus peer $0.38 \pm 0.015 \mathrm{~mm}$. The basic difference of the caecum wall on perimeter at ultrasonic research, is 2.0-2.3 times large thickness of a muscular wall of the organ in the field of tapes. At studying of the colon wall in distal direction the augmentation of thickness of all wall layers becomes perceptible, that corresponds to its morphological structure (Table 1).
The sizes of layers of various departments of colon in teenage (13-16 years) according to ultrasonic research, control group $(n=30)$

\begin{tabular}{|c|c|c|c|}
\hline № & Quantity indicators & \begin{tabular}{|c|}
$\begin{array}{c}\text { Haustration } \\
\text { area }\end{array}$ \\
\end{tabular} & Tapes area \\
\hline \multirow[t]{6}{*}{1} & Caecum (mm) & $1.9 \pm 0.1 *$ & $2.7 \pm 0.1 *$ \\
\hline & 1. serous cover $(\mathrm{mm})$ & $0.3 \pm 0.01$ & $0.2 \pm 0.01$ \\
\hline & 2. muscular layer (mm) & $0.6 \pm 0.09 *$ & $1.4 \pm 0.1 *$ \\
\hline & 3. submucous membrane $(\mathrm{mm})$ & \multicolumn{2}{|l|}{$0.5 \pm 0.025^{*}$} \\
\hline & $\begin{array}{l}\text { 4. muscular plate of mucous } \\
\text { membrane ( } \mathrm{mm})\end{array}$ & \multicolumn{2}{|l|}{$0.2 \pm 0.01$} \\
\hline & 5. mucous membrane (mm) & \multicolumn{2}{|l|}{$0.4 \pm 0.015^{*}$} \\
\hline \multirow[t]{6}{*}{2} & Ascendent colon $(\mathrm{mm})$ & $2.3 \pm 0.15^{*}$ & $3.2 \pm 0.1 *$ \\
\hline & 1.serous cover $(\mathrm{mm})$ & $0.2 \pm 0.012$ & $0.2 \pm 0.01$ \\
\hline & 2. muscular layer (mm) & $0.9 \pm 0.08^{*}$ & $1.75 \pm 0.2^{*}$ \\
\hline & 3.submucous membrane (mm) & \multicolumn{2}{|l|}{$0.6 \pm 0.015^{*}$} \\
\hline & \begin{tabular}{|l|} 
4. muscular plate of mucous \\
membrane $(\mathrm{mm})$
\end{tabular} & \multicolumn{2}{|c|}{$0.25 \pm 0.015$} \\
\hline & 5. mucous membrane $(\mathrm{mm})$ & \multicolumn{2}{|c|}{$0.42 \pm 0.012 *$} \\
\hline \multirow[t]{6}{*}{3} & Transversal colon (mm) & $2.7 \pm 0.11 *$ & $3.8 \pm 0.25^{*}$ \\
\hline & 1. serous cover $(\mathrm{mm})$ & $0.2 \pm 0.01$ & $0.2 \pm 0.01$ \\
\hline & 2. muscular layer (mm) & $1.06 \pm 0.05 *$ & $2.2 \pm 0.14^{*}$ \\
\hline & 3. submucous membrane $(\mathrm{mm})$ & \multicolumn{2}{|l|}{$0.63 \pm 0.03 *$} \\
\hline & $\begin{array}{l}\text { 4. muscular plate of mucous } \\
\text { membrane }(\mathrm{mm})\end{array}$ & \multicolumn{2}{|c|}{$0.29 \pm 0.01$} \\
\hline & 5. mucous membrane (mm) & \multicolumn{2}{|c|}{$0.45 \pm 0.009$} \\
\hline \multirow[t]{6}{*}{4} & Descendent colon (mm) & $3.2 \pm 0.22 *$ & $4.7 \pm 0.29 *$ \\
\hline & 1. serous cover $(\mathrm{mm})$ & $0.27 \pm 0.01$ & $0.28 \pm 0.01$ \\
\hline & 2. muscular layer (mm) & $1.4 \pm 0.2 *$ & $2.83 \pm 0.25 *$ \\
\hline & 3.submucous membrane (mm) & \multicolumn{2}{|l|}{$0.73 \pm 0.03 *$} \\
\hline & $\begin{array}{l}\text { 4. muscular plate of mucous } \\
\text { membrane }(\mathrm{mm})\end{array}$ & \multicolumn{2}{|l|}{$0.32 \pm 0.02 *$} \\
\hline & 5. mucous membrane (mm) & \multicolumn{2}{|l|}{$0.52 \pm 0.03 *$} \\
\hline \multirow[t]{6}{*}{5} & Sigmoid colon (mm) & $4.18 \pm 0.31 *$ & $5.6 \pm 0.2 *$ \\
\hline & 1. serous cover $(\mathrm{mm})$ & $0.28 \pm 0.01$ & $0.3 \pm 0.03$ \\
\hline & 2. muscular layer (mm) & $1.95 \pm \pm 0.2^{*}$ & $3.3 \pm 0.01 *$ \\
\hline & 3. submucous membrane $(\mathrm{mm})$ & \multicolumn{2}{|l|}{$0.85 \pm 0.05^{*}$} \\
\hline & \begin{tabular}{|l|} 
4. muscular plate of mucous \\
membrane $(\mathrm{mm})$
\end{tabular} & \multicolumn{2}{|l|}{$0.37 \pm 0.01$} \\
\hline & 5. mucous membrane (mm) & \multicolumn{2}{|l|}{$0.73 \pm 0.08 *$} \\
\hline \multirow[t]{6}{*}{6} & Rectum (mm) & \multicolumn{2}{|l|}{$6.32 \pm 0.7 *$} \\
\hline & 1. serous cover $(\mathrm{mm})$ & \multicolumn{2}{|l|}{$0.31 \pm 0.01 *$} \\
\hline & 2. muscular layer (mm) & \multicolumn{2}{|l|}{$3.61 \pm 0.31$} \\
\hline & 3. submucous membrane $(\mathrm{mm})$ & \multicolumn{2}{|l|}{$1.1 \pm 0.13^{*}$} \\
\hline & $\begin{array}{l}\text { 4. muscular plate of mucous } \\
\text { membrane (mm) }\end{array}$ & \multicolumn{2}{|l|}{$0.4 \pm 0.09$} \\
\hline & 5. mucous membrane (mm) & \multicolumn{2}{|l|}{$0.9 \pm 0.02 *$} \\
\hline
\end{tabular}

Note: ${ }^{*} \mathrm{p}<0.05$ in comparison on colon departments

Ultrasonic research of the colon wall on an extent is confirmed with results of morphological researches, spent in parallel, and can be used for intraoperative estimations of an organ structure in search of the zones, involved in pathological process. 
During intraoperative ultrasonic research of the colon wall in children with chronic constipation, the greatest changes are defined in sigmoid coIon where its wall thickness increases by 1.4 times $(5.5 \pm 0.4 \mathrm{~mm} ; \mathrm{p}<0.05)$ (Table 2).

Table 2

The layers sizes of the colon wall in different parts of colon in children with decompensated form of chronic constipation according to ultrasonic research

\begin{tabular}{|c|c|c|}
\hline Quantity indicators & $\begin{array}{c}\text { Control group } \\
\text { (haustration } \\
\text { area) } \\
(n=30)\end{array}$ & $\begin{array}{c}\text { Chronic } \\
\text { constipation } \\
\text { group } \\
\text { (haustration } \\
\text { area) } \\
(n=11)\end{array}$ \\
\hline \multicolumn{3}{|l|}{$\begin{array}{l}\text { 1. A descendent } \\
\text { colon }\end{array}$} \\
\hline $\begin{array}{l}\text { - general thickness } \\
\text { of a wall (mm) }\end{array}$ & $3.24 \pm 0.22$ & $3.95 \pm 0.2 *$ \\
\hline $\begin{array}{l}\text { - serous cover } \\
(\mathrm{mm})\end{array}$ & $0.27 \pm 0.01$ & $0.58 \pm 0.12 *$ \\
\hline $\begin{array}{l}\text { - muscular layer } \\
(\mathrm{mm})\end{array}$ & $1.4 \pm 0.15$ & $0.93 \pm 0.12 *$ \\
\hline $\begin{array}{l}\text { - submucous } \\
\text { membrane (mm) }\end{array}$ & $0.73 \pm 0.03$ & $1.37 \pm 0.25 *$ \\
\hline $\begin{array}{l}\text { - muscular plate of } \\
\text { mucous membrane } \\
(\mathrm{mm})\end{array}$ & $0.32 \pm 0.02$ & $0.41 \pm 0.03$ \\
\hline $\begin{array}{l}\text { - mucous } \\
\text { membrane (mm) }\end{array}$ & $0.52 \pm 0.03$ & $0.47 \pm 0.01$ \\
\hline \multicolumn{3}{|l|}{ 3. A sigmoid colon } \\
\hline $\begin{array}{l}\text { - general thickness } \\
\text { of a wall, mm }\end{array}$ & $4.18 \pm 0.31$ & $5.5 \pm 0.4 *$ \\
\hline $\begin{array}{l}\text { - serous cover } \\
(\mathrm{mm})\end{array}$ & $0.28 \pm 0.01$ & $0.65 \pm 0.15 *$ \\
\hline $\begin{array}{l}\text { - muscular layer } \\
(\mathrm{mm})\end{array}$ & $1.95 \pm 0.16$ & $0.91 \pm 0.3^{*}$ \\
\hline $\begin{array}{l}\text { - submucous } \\
\text { membrane (mm) }\end{array}$ & $0.85 \pm 0.05$ & $2.52 \pm 0.2 *$ \\
\hline $\begin{array}{l}\text { - muscular plate of } \\
\text { mucous membrane } \\
(\mathrm{mm})\end{array}$ & $0.37 \pm 0.01$ & $0.29 \pm 0.03$ \\
\hline $\begin{array}{l}\text { - mucous } \\
\text { membrane (mm) }\end{array}$ & $0.73 \pm 0.08$ & $1.13 \pm 0.15^{*}$ \\
\hline
\end{tabular}

Note: $* \mathrm{p}<0.05$ in comparison with normal indicators

At level-by-level studying more than 2.0 times augmentation of serous thickness $(0.65 \pm 0.15 \mathrm{~mm}$; $\mathrm{p}<0.05)$ and submucous membrane thickness $(2.52 \pm 0.2 \mathrm{~mm} ; \mathrm{p}<0.05)$ attracts attention. At the same time reduction of a muscular cover thickness for more than 2 times $(0.91 \pm 0.3 ; p<0.05)$ is taped. At studying of a colon mucosa the augmentation of its thickness up to $1.13 \pm 0.15 \mathrm{~mm}$ is taped $(p<0.05)$, thickness of muscular plate of a mucous membrane authentically does not change (Fig. 2). At ultrasonic research of a wall thickness of descendent colon its changes are less expressed, in proximal direction indicators of the wall thickness are close to normal from the level of the border of descendent and transversal colon or on an extent of the transversal colon, depend-

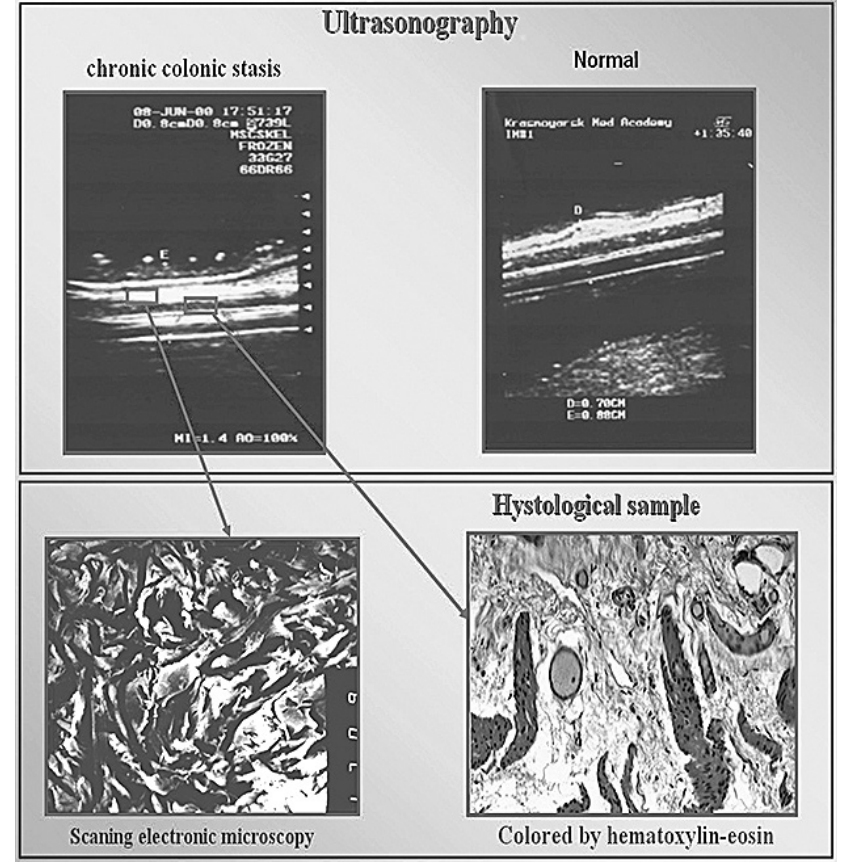

Fig. 2. Comparative relationship between the histological structure, electron microscopy and an ultrasonography data of pathologicaly changed colon wall layers. (Has been showed on upper right, on upper left - normal colon.

The multifrequency linear gauge $9,5 \mathrm{MHz}$ by «Logiq-700»)

ing on expression of pathological process. During the qualitative analysis of layers structure of sigmoid and descendent colon, hyperechoic changes in muscular cover decrease in a proximal direction and come nearer to normal indicators, that is become hypoechoic as in control group. Parallel morphological research of a colon wall confirm the changes taped by ultrasonic method, and reveal that, at reduction of a muscular cover thickness, the augmentation of a serous cover thickness and submucous membrane becomes perceptible and is accompanied by the expressed sclerosis of the specified structures.

Conclusion. Thus, intraoperative ultrasonic research of a colon wall, performed in patients with decompensated form of the chronic constipation, authentic augmentation of a whole wall thickness was taped due to augmentation of serous cover and submucous membrane of an organ with reduction of muscular cover thickness. During research of the colon layers structure, in its most pathological part hyperechoic inclusions are defined. The revealed changes depend on gravity of process, change in proximal direction and come nearer to the normal indicators in transversal colon. The obtained data of ultrasonic researches authentically correlate with morphological indicators. The method of intraoperative estimations (ultrasonic scanning) of pathologically changed zones of an organ, developed and introduced in practice, allows to individualise volume of radical operative measure, to optimise results of surgical treatment in patients with decompensated forms of the chronic constipation. 


\section{References}

1. Kavehmanesh Z., Saburi A., Maavaiyan A. Comparison of body mass index on children with functional constipation and healthy controls. J. Family Med. Prim. Care. 2013;2(3):222-226. doi: 10.4103/2249. 4863.120715.

2. Burgers R., de Jong T. P., Benninga M. A. Rectal examination in children: digital versus transabdominal ultrasound. J. Urol. 2013;190(2):667-672. doi: 10.1016/j.juro.2013.02.3201.

3. Momotov A. A. Colostasis in children. Klin. Khir. $2007 ;(9): 25-27$.

4. Ramesh J., Bang J. Y., Trevino J., Varadarajulu S. Endoscopic ultrasound-guided drainage of pancreatic fluid collections in children. J. Pediatr. Gastroenterol. Nutr. 2013;56(1):30-35. doi: 10.1097/MPG. Ob013e318267c113.

5. Lenyushkin A. I. Children proctology Medicine. Moscow; 1999, $400 \mathrm{p}$

6. Agarwal J. Chronic constipation. Indian J. Pediatr. 2013;80(12):1021-1025. doi: 10.1007/s12098-0131133-5.

7. Kirgizov I., Prudnikova T., Abayhanov R., Aprosimov M., Minaev S. et al. Surgical treatment of the rectal forms of Hirshprungs disease in children. 4th World Congress of Pediatric Surgery. Abstract book. Berlin, Germany 13 - 16 October; 2013:7/3.

8. Haji A., Adams K., Bjarnason I., Papagrigoriadis S. Highfrequency mini probe ultrasound before endoscopic resection of colorectal polyps - is it useful? Dis. Colon Rectum. 2014;57(3):378-382. doi: 10.1097/ DCR.0b013e3182a0e39c.

\section{THE ULTRASONIC WAY OF THE INTRAOPERATIVE ASSESS OF THE RESECTION VOLUME OF COLON IN CHILDREN WITH CHRONIC CONSTIPATION KIRGIZOV I. V., MINAEV S. V.}

Research of 30 histological specimen of colon (autopsy material of normal colon wall) allows differentiating 5 layers in its wall. At intraoperative ultrasonic research of a colon wall in patients with chronic constipation, specific changes like hyperechoic inclusions in a wall structures are taped, that allows to define a degree of the specified changes and thereby resection level. Bench ultrasonic researches of various departments and colon sites, carried out on 30 histological specimens of colon, consisted of autopsy material gives rather detailed picture of the wall structure of an organ. The most important characteristics of the examined parts are the thickness of every layer and its echogenicity. During operations in 11 patients with decompensated forms of the chronic constipation, we managed to carry out an intraoperative ultrasonic diagnostics of the colon wall that was very important for differentiation of the changed parts of the organ, which required resection. With ultrasonic examination of the changed structure of the organ, special attention should be paid to the authentic increasing of the thickness of muscular layer of colon wall in a proximal way and decreasing of the submucous and subserous membranes thickness.

Key words: a chronic constipation, ultrasound, children
9. Gijsbers C.F., Benninga M., Büller H. Clinical and laboratory findings in 220 children with recurrent abdominal pain. Acta Paediatr. 2011;100(7):1028-1032. doi: 10.1111/j.1651-2227.2011.02179.x

10. Burr A., Renaud E. J., Manno M., Makris J., Cooley E. et al. Glowing in the dark: time of day as a determinant of radiographic imaging in the evaluation of abdominal pain in children. J. Pediatr. Surg. 2011;46(1):188191. doi: 10.1016/j.jpedsurg.2010.09.088.

11. Nicolau A. E., Merlan V., Dinescu G., Crăciun M., Kitkani A., Beuran M. Perforation of hollow organs in the abdominal contusion: diagnostic features and prognostic factors of death. Chirurgia (Bucur). 2012;107(2):162-168.

12. Tappin D., Nawaz S., McKay C., MacLaren L., Griffiths P., Mohammed T. A. Development of an early nurse led intervention to treat children referred to secondary paediatric care with constipation with or without soiling. BMC Pediatr. 2013;13:193. doi: 10.1186/1471-2431-13-193.

13. Minaev S. V., Kirgizov I. V., Obedin A. N., Isaeva A. V., Bolotov Yu. N. et al. Monitoring of inflammatory complications development in the newborns with congenital pathology of the gastrointestinal tract. Medicinskii Vestnik Severnogo Kavkaza. - Medical News of North Caucasus. 2013;8(2):30-33.

14. Peeraully M. R., Lopes J., Wright A., Davies B. W., Stewart R. J. et al. Experience of the MACE procedure at a regional pediatric surgical unit: a 15-year retrospective review. Eur. J. Pediatr. Surg. 2014;24(1):113-116. doi: 10.1055/s0033-1357502.

15. Chogle A., Saps M. Yield and cost of performing screening tests for constipation in children. Can. J. Gastroenterol. 2013;27(12):e35-38.

\section{ИНТРАОПЕРАЦИОННЫЙ УАЬТРАЗВУКОВОЙ СПОСОБ ОПРЕАЕАЕНИЯ ОБЪЁМА РЕЗЕКЦИИ ТОАСТОЙ КИШКИ У БОАЬНЫХ АЕТЕЙ С ХРОНИЧЕСКИМ ТОАСТОКИШЕЧНЫМ СТАЗОМ И. В. КИРГИЗОВ, С. В. МИНАЕВ}

Изучение 30 препаратов толстой кишки детей в норме позволило дифференцировать в её стенке 5 оболочек (серозная, мышечная, подслизистая, мышечная пластинка слизистой и слизистая оболочка), их структуру, что соответствует полностью морфологическому строению. У детей с хроническим толстокишечным стазом при интраоперационном ультразвуковом исследовании стенки толстой кишки выявлены специфические изменения в виде включения гиперэхогенных структур, которые позволили определить степень указанных изменений и уровень резекции.

Ключевые слова: хронический толстокишечный стаз, ультразвуковое исследование, дети 